\title{
Temperature-mediated feeding between spring-associated and riverine-associated congeners, with implications for community segregation
}

\author{
Cody A Craig ${ }^{\text {Corresp., }}{ }^{1}$, Jeremy D Maikoetter ${ }^{1}$, Timothy H Bonner $^{1}$ \\ 1 Department of Biology/ Aquatic Station, Texas State University, San Marcos, Texas, United States \\ Corresponding Author: Cody A Craig \\ Email address: cac300@txstate.edu
}

Freshwater fish communities segregate along water temperature gradients attributed in part to temperature-mediated physiological processes that affect species fitness. In spring complexes of southwest USA, spring complexes with narrow range of water temperatures are dominated by a community of fishes (i.e., spring-associated fishes), whereas riverine habitats with wide-range of water temperatures are dominated by a different community of fishes (i.e., riverine-associated fishes). The purpose of this study was to test a prediction of the concept that temperature-mediated species performance is a mechanism in maintaining community segregation. We predicted that a spring-associated fish (Largespring Gambusia Gambusia geiseri) would feed first and more often in a pairing with a riverine-associated fish (Western Mosquitofish Gambusia affinis) at an average spring temperature $\left(23^{\circ} \mathrm{C}\right)$ and that the riverine-associated fish would feed first and more often in a pairing with the spring-associated fish at a warm riverine temperature $\left(30^{\circ} \mathrm{C}\right)$. Among four trails consisting of 30 pairings, at the spring complex temperature $\left(23^{\circ} \mathrm{C}\right)$, Largespring Gambusia had a greater number of first feeds (mean \pm 1 SD, $5.0 \pm 0.82$ ) than Western Mosquitofish $(2.5 \pm 1.73)$ and had greater mean number of total feeds $(1.9 \pm 0.31)$ than Western Mosquitofish $(0.81 \pm 0.70)$. At the riverine environment temperature $\left(30^{\circ} \mathrm{C}\right)$, Western Mosquitofish had a greater number of first feeds $(5.25 \pm 1.71)$ than Largespring Gambusia $(2.5 \pm 1.73)$ and had greater mean number of total feeds $(2.78 \pm 1.05)$ than Largespring Gambusia (0.94 \pm 0.68$)$. Our findings suggest that temperature-mediated species performance could be maintaining segregation between the two fish communities. This study benefits our understanding of distributional patterns and improves threat assessments of stenothermal aquatic organisms. 
2 Temperature-mediated feeding between spring-associated and riverine-associated

3 congeners, with implications for community segregation

4 Cody A. Craig ${ }^{1}$, Jeremy D. Maikoetter ${ }^{1}$, and Timothy H. Bonner ${ }^{1}$

$5{ }^{1}$ Department of Biology/Aquatic Station, Texas State University, San Marcos, Texas 78666.

6

7

$8 *$ Corresponding Author

9 Cody A. Craig 1

10 E-mail: cac300@txstate.edu (CAC) 
12 Freshwater fish communities segregate along water temperature gradients attributed in part to temperature-mediated physiological processes that affect species fitness. In spring complexes of southwest USA, spring complexes with narrow range of water temperatures are dominated by a community of fishes (i.e., spring-associated fishes), whereas riverine habitats with wide-range of water temperatures are dominated by a different community of fishes (i.e., riverine-associated fishes). The purpose of this study was to test a prediction of the concept that temperaturemediated species performance is a mechanism in maintaining community segregation. We predicted that a spring-associated fish (Largespring Gambusia Gambusia geiseri) would feed first and more often in a pairing with a riverine-associated fish (Western Mosquitofish Gambusia affinis $)$ at an average spring temperature $\left(23^{\circ} \mathrm{C}\right)$ and that the riverine-associated fish would feed first and more often in a pairing with the spring-associated fish at a warm riverine temperature $\left(30^{\circ} \mathrm{C}\right)$. Among four trials consisting of 30 pairings at the spring complex temperature $\left(23^{\circ} \mathrm{C}\right)$, Largespring Gambusia had a greater number of first feeds (mean $\pm 1 \mathrm{SD}, 5.0 \pm 0.82$ ) than Western Mosquitofish $(2.5 \pm 1.73)$ and had greater mean number of total feeds $(1.9 \pm 0.31)$ than Western Mosquitofish $(0.81 \pm 0.70)$. At the riverine environment temperature $\left(30^{\circ} \mathrm{C}\right)$, Western Mosquitofish had a greater number of first feeds $(5.25 \pm 1.71)$ than Largespring Gambusia $(2.5 \pm$ $1.73)$ and had greater mean number of total feeds $(2.78 \pm 1.05)$ than Largespring Gambusia $(0.94$ \pm 0.68 ). Our findings suggest that temperature-mediated species performance could be maintaining segregation between the two fish communities. This study benefits our understanding of distributional patterns and improves threat assessments of stenothermal aquatic organisms. 


\section{Introduction}

Aquatic species and communities are distributed along altitudinal, geographical, and

longitudinal gradients where habitats, food resources, predation, and water quality conditions differ (Vannote et al., 1980; Taniguchi \& Nakano, 2000). Among freshwater fishes, water temperature is one of several described mechanisms regulating distributional patterns (Grossman \& Freeman, 1987). Temperature can influence interspecific interactions within freshwater fish communities when species temperature tolerances are overlapping (Taniguchi et al., 1998).

Temperature-mediated interactions and its influence on species distributions, though difficult to quantify in nature (Gerking, 1994), are supported in laboratory experiments. Taniguchi et al. (1998) and Taniguchi \& Nakano (2000) compared water temperature tolerances and behaviors among fishes distributed along an altitudinal gradient and found fish that inhabit cooler water at higher altitudes was more aggressive, consumed more food, had faster growth, and greater survival rate at cooler temperatures than lower altitude fishes. Conversely, fishes, which inhabit warmer water at lower altitudes, were more aggressive, consumed more food, and had faster growth at warmer temperatures than the higher altitude fish. Carmona-Catot, Magellan \& Garcia-Berthou (2013) quantified pairwise feeding performance at three temperatures (i.e., 19, 24 , and $29^{\circ} \mathrm{C}$ ) of an introduced warm-water cyprinodont and a native cool-water cyprinodont to assess temperature-mediated interactions in non-native species range expansion and native species extirpation potential. The invasive warm-water cyprinodont had a lower food capture rate compared to the native cool-water cyprinodont at the coolest temperature. At warmer temperatures, the invasive warm-water cyprinodont had a greater food capture rate compared to native cool-water cyprinodont. Laboratory results of temperature-mediated interactions suggest water temperature regulates fish distributions. 

refugia with stenoecious water quality, including thermally-constant water temperatures (i.e., stenothermal habitat; range $21.0-23.3^{\circ} \mathrm{C}$ ), and distinct fish communities consisting of springassociated fishes that have greater relative abundances and densities within spring complexes (Craig et al., 2016). As spring complexes transition downstream into riverine environments with less thermally-constant water temperatures (i.e., eurythermal habitat; range: $6-30^{\circ} \mathrm{C}$ ) attributed to ambient conditions and merging with higher order streams, relative abundances and densities of spring-associated fishes are reduced and different species of fishes (i.e., riverine-associated fishes) become dominant. Similar to altitudinal gradients (Taniguchi et al., 1998; Taniguchi \& Nakano, 2000), water temperature is a suggested mechanism in regulating richness, abundances, and densities of spring-associated fishes and riverine-associated fishes (Hubbs, 1995; Kollaus \& Bonner, 2012) with spring-associated fishes being potentially more fit in stenothermal habitats and riverine-associated fishes being potentially more fit in eurythermal habitats. Dissimilar to altitudinal gradients, spring-associated fishes and riverine-associated fishes do not represent previously researched cold-water and warm-water forms with overlapping tolerances, but both are warm-water forms having similar temperature tolerances (Hagen, 1964; Brandt et al., 1993). And similar reproductive tolerances (Bonner et al., 1998; McDonald et al., 2007). In marine systems, species in stenothermal habitats might select away from eurythermal enzymes and proteins (Graves \& Somero, 1982) and select for proteins and enzymes that are more energy efficient within a narrow range of temperatures (Pörtner, Peck \& Somero, 2007), whereas species

77 in eurythermal habitats are suggested to conserve temperature-dependent enzymes and proteins that enable tolerance of wide-ranging water temperatures (Somero, Dahlhoff \& Lin, 1996). Differences in fitness between spring-associated fishes in stenothermal habitats and riverine- 
80

81

82

83

84

85

86

87

88

89

90

91

92

93

94

98

99

100

associated fishes in eurythermal habitats could explain patterns in fish community segregation in spring-river systems.

The purpose of this study was to test predictions of the concept that stenothermal habitat of spring complexes is a factor in maintaining community segregation between spring-associated and riverine-associated fishes. The study objective was to quantify feeding (i.e., first feed and number of total feeds) as a measure of performance between spring-associated and riverineassociated fish pairs at two water temperatures and determine if water temperatures favored one species over the other. Water temperatures selected were $23^{\circ} \mathrm{C}$, a typical water temperature in spring complexes, and $30^{\circ} \mathrm{C}$, a typical summertime temperature in riverine environments. We used two congeneric species, the riverine-associated Western Mosquitofish, Gambusia affinis (Fig. 1A) and the spring-associated Largespring Gambusia, Gambusia geiseri (Fig. 1B); Hubbs, Edwards \& Garrett, 2008). Both species have similar thermal tolerances (Hagen, 1964) and mostly abutted distributions in spring-river systems (Watson, 2006; Behen, 2013). If water temperature mediates feeding and therefore potential interactions, we predict G. geiseri will eat first and eat more food items than G. affinis at $23^{\circ} \mathrm{C}$ and G. affinis will eat first and eat more food items than $G$. geiseri at $30^{\circ} \mathrm{C}$. Ability to identify stenothermic aquatic organisms and quantify temperature-mediated segregation will benefit our understanding of distributional patterns and improve threat assessments. 

geiseri were collected from a site $\left(29^{\circ} 53^{\prime} 22.2^{\prime \prime} \mathrm{N}, 9^{\circ} 56^{\prime} 03.7^{\prime \prime} \mathrm{W}\right)$ on the San Marcos River.

Gambusia affinis were collected from a site $\left(29^{\circ} 54^{\prime} 43.8^{\prime \prime} \mathrm{N}, 97^{\circ} 53^{\prime} 50.3^{\prime \prime} \mathrm{W}\right)$ on the Blanco River approximately 13 river kilometers away from the Gambusia geiseri collection site. Both species were collected from respective sites within the same day. Sexually-mature Gambusia $>20 \mathrm{~mm}$ in total length (TL) (Stevens, 1977; Haynes \& Cashner, 1995) were retained. Fishes were transported using insulated 52-L coolers to a laboratory at Texas State University Freeman Aquatic Biology Building within 30 minutes of capture. Within the laboratory, fishes were drip acclimated for $24 \mathrm{~h}$ to $23^{\circ} \mathrm{C}$ with well water from the Edwards Aquifer, which is the same water source as the San Marcos and Blanco rivers (Groeger et al., 1997) and followed approved Texas State University Institutional Animal Care and Use Committee protocol (approval number: 201658034). Fishes were separated by species and placed into 35-L glass aquaria submersed in a LS-700 Living Stream (Frigid Units, Inc.). Each aquarium was equipped with a sponge filter. The Living Stream utilized a dual feedback heating and cooling system to maintain desired 116 temperature within $\pm 0.5^{\circ} \mathrm{C}$. Photoperiod was $14 \mathrm{~h}$ light:10 h dark. To maintain water quality, $50 \%$ water changes by volume were completed every $48 \mathrm{~h}$. Fishes were fed high protein BioDiet

118 Grower $1.2 \mathrm{~mm}$ (Bio-Oregon) daily ad libitum. To avoid any learned feeding behaviors, fishes 119 were fed at varying times throughout the day and various locations of the aquaria. For $23^{\circ} \mathrm{C}$ 120 feeding trials, food was withheld $24 \mathrm{~h}$ prior to feeding trials. For $30^{\circ} \mathrm{C}$ feeding trials, water 121 temperature was adjusted $1^{\circ} \mathrm{C}$ per day for $7 \mathrm{~d}$ (Carmona-Catot, Magellan \& Garcia-Berthou, 122 2013). Fishes remained at $30^{\circ} \mathrm{C}$ for $48 \mathrm{~h}$ before use in feeding trials, and food withheld $24 \mathrm{~h}$ prior 
123 to feeding trials. Fishes were kept in the laboratory for a total of three days for the $23^{\circ} \mathrm{C}$ trial, and

124 ten days for the $30^{\circ} \mathrm{C}$ trial.

125 For pairwise feeding trials, one G. geiseri and one G. affinis were visually size (i.e.,

126 within $5 \mathrm{~mm}$ ) and sex matched (Carmona-Catot, Magellan \& Garcia-Berthou, 2013), placed into

127 a $1.25-\mathrm{L}$ opaque container (23 x $15 \mathrm{~cm}$ area), and allowed to acclimate for 1 hour. The container

128 was immersed in the Living Stream to maintain the target temperature within $\pm 0.5^{\circ} \mathrm{C}$. Five

129 natural prey items (Order Trichoptera, Family Hydroptilidae; Sokolov \& Chvaliova, 1936) were

130 placed into the center of the container using a plastic pipette. The species of the individual

131 feeding (i.e., strikes that consumed all, part, or none of the prey) first was recorded and total

132 feeds were recorded for both individuals. Each pairwise trial was limited to five minutes or until

133 all food items were consumed. After completion, fishes were euthanized in MS-222 (Tricane-S)

134 and preserved in 10\% formalin; therefore, a fish was used only once in a feeding trial. For a no

135 feed trial, the two individuals were given an additional 30 minutes to acclimate and tried for an

136 additional trial. Four independent test batches were conducted at $23^{\circ} \mathrm{C}$ and $30^{\circ} \mathrm{C}$. A test batch

137 was defined as all successful feeding trials at a certain temperature conducted within a $4-6 \mathrm{~h}$

138 period. All test batches were conducted between May 2017 and July 2017. Targeted number of

139 pairwise matches was 10 to 11 per batch, but fish jumped out of the container on four occasions,

140 and neither fish eating after 30 minutes occurred on 16 occasions. For both instances, the

141 pairwise trial was ended and recorded observations were discarded.

Number of first feeds and mean number of total feeds were calculated for each species by

143 target temperature. Number of first feeds was calculated by summing the number of first feeds

144 by species per batch. Mean number of total feeds was calculated by summing of total feeds by

145 species in each batch and dividing by the number of pairwise trials. One tailed two sample t-tests 
146 (SAS Institute, Gary, North Carolina) were used to detect differences in first feeds and mean

147 number of total feeds between species at $23^{\circ} \mathrm{C}$ and $30^{\circ} \mathrm{C}$. Use of one tailed t-tests were justified

148 by the a priori prediction that the spring-associated fish would outperform at $23^{\circ} \mathrm{C}$ and the

149 riverine-associated fish would outperform at $30^{\circ} \mathrm{C}$.

At $23^{\circ} \mathrm{C}, 30$ pairwise first feeds and 82 total feeds were observed out of 150 food items

offered between G. geiseri and G. affinis pairs among four batches. Number of first feeds was feeds was greater $(t=2.82, \mathrm{df}=6, P=0.02)$ for $G$. geiseri than $G$. affinis. offered between G. geiseri and G. affinis pairs among four batches. Number of first feeds was greater $(t=2.26, \mathrm{df}=6, P=0.03)$ for $G$. affinis than $G$. geiseri. Mean number of total feeds was greater $(t=2.94, \mathrm{df}=6, P=0.01)$ for $G$. affinis than $G$. geiseri.

\section{Discussion} riverine-associated $G$. affinis at a temperature typical of a spring complex, and conversely, $G$. 
168 mediated feeding performances among families, genera, and species reported by others (De staso

169 \& Rahel, 1994; Taniguchi et al., 1998; Taniguchi \& Nakano, 2000; Carmona-Catot, Magellan \&

170 Garcia-Berthou, 2013). This study, however, is novel in that it documents temperature-mediated

171 performance between a spring-associated fish and a riverine-associated fish with similar thermal

172 tolerances (Hagen 1964). Greater feeding performance of G. affinis at a water temperature of

$17330^{\circ} \mathrm{C}$ corresponds with the reported fastest growth rates and greatest natality rates of G. affinis at

$17430^{\circ} \mathrm{C}$ when compared to 20 and $25^{\circ} \mathrm{C}$ (Vondracek, Wurtsbaugh \& Cech, 1988). Our results and

175 the findings of Vondracek Wurtsbaugh \& Cech (1988) suggest that a warmer water temperature

176 increases physiological and feeding performance of G. affinis, which corresponds with

177 distributions of G. affinis during summertime in riverine environments. Conversely, a water

178 temperature typical of spring complexes increases feeding performance for G. geiseri, which

179 corresponds with distributions of $G$. geiseri during summertime in spring complexes. Growth

180 rates, natality rates, and other measures of physiology are not known at this time for G. geiseri.

181 Additionally, influences of other abiotic differences between spring systems and riverine systems

182 (e.g., pH, specific conductance, and turbidity; Groeger et al., 1997) have not been assessed as to 183 their role underlying G. geiseri and G. affinis segregation.

In order to show ubiquity of temperature-mediated performance as a mechanism for segregation among species distributions, feeding comparisons in addition to quantification of other temperature-mediated performance measures (e.g., growth and swimming performance) can be assessed for several other closely related taxa with similar distributions as $G$. geiseri and G. affinis within spring-river systems, such as spring-associated Etheostoma lepidum (Hubbs, 1985 ) and riverine-associated E. spectabile, E. fonticola (Bonner \& McDonald, 2005) and E. proeliare, Cyprinella proserpina (Hubbs, 1995) and C. lutrensis, Dionda argentosa (Garrett, 
191 Hubbs \& Edwards, 2002) and D. diaboli, and Ictalurus lupus (Sublette, Hatch \& Sublette, 1990)

192 and I. punctatus. In addition, spring-associated fishes and riverine-associated fishes maintain

193 segregation during the winter when water temperatures of riverine environments are colder than

194 water temperatures of spring complexes (Kollaus \& Bonner, 2012). Assessments of feeding

195 performance among spring-associated fishes and riverine-associated fishes at typical winter time

196 temperatures would complete the range of conditions in which segregation is maintained.

197 Ultimately, quantification of genetic, physiological, and biochemical mechanisms will be

necessary to describe underlying temperature-mediated performance of spring-associated and

riverine-associated species (see review in Somero, Dahlhoff \& Lin, 1996). At a minimum,

known mechanisms for stenotherm radiation and maintenance can serve as a basis for

understanding evolutionary origins and maintenance of segregation among spring-associated and riverine-associated fishes.

Ability to identify stenothermic aquatic organisms and to quantify temperature-mediated segregation will benefit our understanding of distributional patterns and improve threat assessments. Stenothermic organisms are potentially more sensitive to temperature changes related to physical habitat alterations and global climate change than eurythermic organisms because of the lack of gene product selection associated with eurythermic organisms (Somero, Dahlhoff \& Lin, 1996). Physical habitat alterations include instream or riparian modifications that manipulate the energy budget or thermal capacity of the surface water (Poole \& Berman, 2001), such as discharge of heated effluents (Langford, 1990; Olden \& Rahel, 2008), removal of riparian vegetation (Moore, Spittlehouse \& Story, 2005), stream channel modification (Nelson \&

212 Palmer, 2007), dams and diversions (Olden \& Naiman, 2010), and reduction of discharge through groundwater pumping (Sinokrot \& Gulliver, 2000). Groundwater sources supporting 
214 spring complexes of southwest USA are commodities (Loaiciga, 2003), and groundwater harvest

215 is linked to the loss of spring complexes and associated biota (Craig \& Bonner, unpublished data

216 ; Winemiller \& Anderson, 1997). Within the Edwards Plateau, there are eight federally listed and

21712 Texas state listed fishes that are associated with spring complexes. Our manuscript supports

218 why spring-associated fishes are found within spring complexes, which informs natural resource

219 managers in supervising species and their habitats (e.g., minimize groundwater withdrawals

220 during periods of natural low flow periods to maintain stenothermal habitats for the spring

221 fishes). Continued climate change in North America is predicted to alter stream flow patterns,

222 increasing storm events, decreased dissolved oxygen, and increases in groundwater temperatures

223 (Poff, Brinson \& Day, 2002; Ficke, Myrick \& Hansen, 2007). As with physical habitat

224 alterations, stenothermic aquatic organisms are predicted to follow isoclines of suitable habitat

225 (Ficke, Myrick \& Hansen, 2007), remain in place and wait for better times, adapt to changes, or

226 become extinct (Clarke, 1996).

\section{Conclusions}

230

231

232

233

234

235

This study supports a prediction that temperature mediates species distribution of a springassociated and a riverine-associated fish through laboratory trials. Novel results of this study show temperature-mediated feeding performance of two species with similar temperature tolerances that inhabit spring-river systems. Although further work is needed to test for the ubiquity among other fishes, this study suggests temperature to be a structuring mechanism for organisms in spring-river systems. 


\section{Acknowledgements}

239 We would like to thank numerous graduate and undergraduate students for assistance with field

240 collections. We would also like to thank C. Gabor for suggestions and guidance on concept and 241 study design. 


\section{Literature Cited}

Behen KP. 2013. Influence of connectivity and habitat on fishes of the upper San Marcos River. M. Sc. Thesis, Texas State University.

Bonner TH., Brandt TM., Fries JN., Whiteside BG. 1998. Effects of temperature on egg production and early life stages of the Fountian Darter. Transactions of the American Fisheries Society 127:971-978.

Bonner TH., McDonald DL. 2005. Threatened fishes of the world: Etheostoma fonticola (Jordan \& Gilbert 1886) (Percidae). Environmental Biology of Fishes 73:333-334. DOI: 10.1007/s10641-004-4132-6.

Brandt TM., Graves KG., Berkhouse CS., Simon TP., Whiteside BG. 1993. Laboratory Spawning and Rearing of the Endangered Fountain Darter. The Progressive Fish-Culturist 55:149-156. DOI: $10.1577 / 1548-8640(1993) 055<0149$.

Carmona-Catot G., Magellan K., Garcia-Berthou E. 2013. Temperature-Specific Competition between Invasive Mosquitofish and an Endangered Cyprinodontid Fish. PLoS ONE 8. DOI: 10.1371/journal.pone.0054734.

Clarke A. 1996. The influence of climate change on the distribution and evolution of organisms. In: Animals and temperature phenotypic and evolutionary adaptation. Cambridge Universiy Press, 419.

Craig CA., Kollaus KA., Behen KPK., Bonner TH. 2016. Relationships among spring flow, habitats, and fishes within evolutionary refugia of the Edwards Plateau. Ecosphere 7. DOI: 10.1002/ecs2.1205.

De Staso., Rahel FJ. 1994. Influence of water temperature on interactions between juvenile Colorado River Cutthroat Trout and Brook Trout in a laboratory stream. Transactions of the American Fisheries Society 123:289-297.

Ficke AD., Myrick CA., Hansen LJ. 2007. Potential impacts of global climate change on freshwater fisheries. Reviews in Fish Biology and Fisheries 17:581-613. DOI: 10.1007/s11160-007-9059-5.

Garrett GP., Hubbs C., Edwards RJ. 2002. Threatened fishes of the world : Dionda diaboli Hubbs \& Brown, 1956 ( Cyprinidae ). 1956:56609.

Gerking S. 1994. Feeding Ecology of Fish. San Diego: Academic Press.

Graves JE., Somero GN. 1982. Electrophoretic and functional enzymatic evolution in 4 species of eastern pacific barracudas from different thermal environments. Evolution 36:97-106.

Groeger A., Brown P., Titjen T., Kelsey T. 1997. Water Quality of The San Marcos River. Texas Journal of Science 49.

Grossman GD., Freeman MC. 1987. Microhabitat use in a stream fish assemblage. Journal of 
280

281

282

283

284

285

286

287

288

289

290

291

292

293

294

295

296

297

298

299

300

301

302

303

304

305

306

307

308

309

310

311

312

313

314

315

316

Hagen DW. 1964. Evidence of adaptation to environmental temperatures in three species of Gambusia. The Southwestern Naturalist 9:6-19. DOI: 10.2307/3669098.

Haynes JL., Cashner RC. 1995. Life history and population dynamics of the western mosquitofish: a comparison of natural and introduced populations. Journal of Fish Biology 46:1026-1041. DOI: 10.1111/j.1095-8649.1995.tb01407.x.

Hubbs C. 1985. Darter Reproductive Seasons. American Society of Ichthyologists and Herpetologists 1985:56-68.

Hubbs C. 1995. Springs and Spring Runs as Unique Aquatic Systems. American Society of Ichthyologists and Herpetologists 4:989-991.

Kollaus KA., Bonner TH. 2012. Habitat associations of a semi-arid fish community in a karst spring-fed stream. Journal of Arid Environments 76:72-79. DOI: 10.1016/j.jaridenv.2011.08.013.

Langford T. 1990. Ecological effects of thermal discharges. Springer Science \& Buisness Media.

Loaiciga HA. 2003. Climate Change and Ground Water. Annals of the Association of American Geographers 93:30-41.

McDonald DL., Bonner TH., Oborny EL., Brandt., TM. 2007. Effects of fluctuating temperatures and gill parasites on reproduction of the Fountain Darter, Etheostoma fonticola. Journal of Freshwater Ecology 22: 311-318.

Moore RD., Spittlehouse DL., Story A. 2005. Riparian microclimate and stream temperature response to forest harvesting: A review. Journal of the American Water Resources Association 41:813-834. DOI: 10.1111/j.1752-1688.2005.tb03772.x.

Nelson KC., Palmer MA. 2007. Stream temperature surges under urbanization and climate change: Data, models, and responses. Journal of the American Water Resources Association 43:440-452. DOI: $10.1111 /$ j.1752-1688.2007.00034.x.

Olden JD., Naiman RJ. 2010. Incorporating thermal regimes into environmental flows assessments: Modifying dam operations to restore freshwater ecosystem integrity. Freshwater Biology 55:86-107. DOI: 10.1111/j.1365-2427.2009.02179.x.

Olden JD., Rahel FJ. 2008. Assessing the Effects of Climate Change on Aquatic Invasive Species. Conservation Biology 22:521-533. DOI: 10.1111/j.1523-1739.2008.00950.x.

Poff NL., Brinson MM., Day JW. 2002. Aquatic ecosystems and global climate change. Pew Center on Global Climate Arlington, VA. Available at https://rydberg.biology.colostate.edu/poff/Public/poffpubs/Poff2002(PEW_AquaticEcosys). pdf

Poole GC., Berman CH. 2001. An Ecological Perspective on In-Stream Temperature: Natural Heat Dynamics and Mechanisms of Human-CausedThermal Degradation. Environmental Management 27:787-802. DOI: 10.1007/s002670010188.

Pörtner HO., Peck L., Somero GN. 2007. Thermal limits and adaptation in marine Antarctic 
ectotherms : an integrative view. Philosophical transactions of the Royal Society of London. Series B, Biological sciences 362:2233-2258. DOI: 10.1098/rstb.2006.1947.Sinokrot BA., Gulliver JS. 2000. In-stream flow impact on river water temperatures. Journal of Hydraulic Research 38:339-349. DOI: 10.1080/00221680009498315.

Sokolov NP., Chvaliova MA. 1936. Nutrition of Gambusia affinis on the rice fields of Turkestan. Journal of Animal Ecology 5:390-395.

Somero G., Dahlhoff E., Lin J. 1996. Stenotherms and eurytherms: mechanisms establishing thermal optima and tolerance ranges. In: Animals and temperature phenotypic and evolutionary adaptation. 53-78.

Stevens FB. 1977. Patterns in the reproductive ecology of Gambusia geiseri. D. Phil. Dissertation, University of Texas.

Sublette JE., Hatch MD., Sublette M. 1990. The fishes of New Mexico. Albuquerque, New Mexico: University New Mexico Press.

Taniguchi Y., Nakano S. 2000. Condition-Specific Competition : Implications for the Altitudinal Distribution of Stream Fishes. Ecology 81:2027-2039.

Taniguchi Y., Rahel FJ., Novinger DC., Gerow KG. 1998. Temperature mediation of competitive interactions among three fish species that replace each other along longitudinal stream gradients. Canadian Journal of Fisheries and Aquatic Sciences 55:1894-1901. DOI: 10.1139/f98-072.

Thomas C., Bonner TH., Whiteside BG. 2007. Freshwater fishes of Texas. Texas A\&M University Press

Vannote RL., Minshall GW., Cummins KW., Sedell JR., Cushing CE. 1980. The river continuum concept. Canadian Journal of Fisheries and Aquatic Sciences 37:130-137.

Vondracek B., Wurtsbaugh WA., Cech JJ. 1988. Growth and reproduction of the mosquitofish, Gambusia affinis, in relation to temperature and ration level: consequences for life history. Environmental Biology of Fishes 21:45-57. DOI: 10.1007/BF02984442.

Watson JM. 2006. Patterns and habitat associations of a desert spring fish assemblage and responses to a large-scale flood. M. Sc. Thesis, Texas State University.

Winemiller KO., Anderson A a. 1997. Response of Endangered Desert Fish Populations to a Constructed Refuge. Restoration Ecology 5:204-213. DOI: 10.1046/j.1526100X.1997.09725.x. 
Figure 1

Gambusia affinis and Gambusia geiseri

Example of species (A) Gambusia affinis female and (B) Gambusia geiseri male used in study. Picture from Thomas, Bonner, and Whiteside (2007).

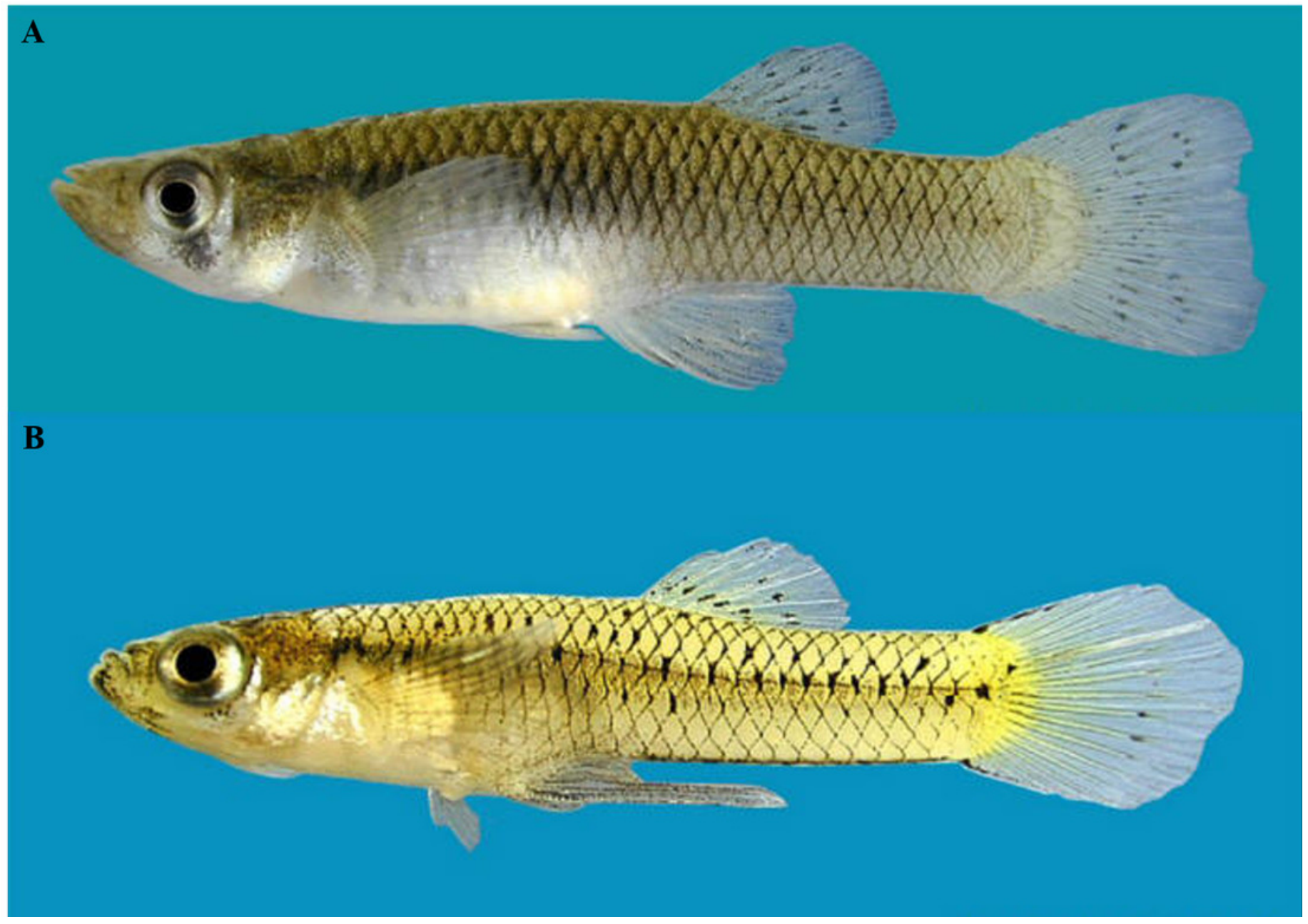




\section{Table $\mathbf{1}$ (on next page)}

Number of first feeds and mean number of total feeds by batch for Gambusia geiseri and Gambusia affinis at $23^{\circ} \mathrm{C}$ and $30^{\circ} \mathrm{C}$. 


\begin{tabular}{|c|c|c|c|c|c|c|}
\hline \multirow[b]{2}{*}{ Temperature } & \multirow[b]{2}{*}{ Batch } & \multirow[b]{2}{*}{$\mathrm{N}$ of pairs } & \multicolumn{2}{|c|}{ Number of first feeds } & \multicolumn{2}{|c|}{ Mean number of total feeds } \\
\hline & & & G. geiseri & G. affinis & G. geiseri & G. affinis \\
\hline \multirow[t]{6}{*}{$23^{\circ} \mathrm{C}$} & 1 & 7 & 5 & 2 & 2.29 & 0.29 \\
\hline & 2 & 6 & 4 & 2 & 2.00 & 0.83 \\
\hline & 3 & 6 & 5 & 1 & 1.60 & 0.33 \\
\hline & 4 & 11 & 6 & 5 & 1.70 & 1.80 \\
\hline & Mean & & 5.00 & 2.50 & 1.90 & 0.81 \\
\hline & $\mathrm{SD}$ & & 0.82 & 1.73 & 0.31 & 0.70 \\
\hline \multirow[t]{6}{*}{$30^{\circ} \mathrm{C}$} & 1 & 9 & 3 & 6 & 1.44 & 2.11 \\
\hline & 2 & 7 & 4 & 3 & 1.43 & 2.71 \\
\hline & 3 & 7 & 0 & 7 & 0.00 & 4.29 \\
\hline & 4 & 8 & 3 & 5 & 0.88 & 2.00 \\
\hline & Mean & & 2.50 & 5.25 & 0.94 & 2.78 \\
\hline & $\mathrm{SD}$ & & 1.73 & 1.71 & 0.68 & 1.05 \\
\hline
\end{tabular}

2 